Newly qualified teachers' understandings of research-based teacher education practices - Two cases from Finland and Norway

Rachel Jakhelln, Gunilla Eklund, Jessica Aspfors, Kristin Bjørndal, Gerd Stølen

\title{
Affiliations
}

\section{Rachel Jakhelln,}

Department of Education, The Arctic University of Norway, Norway (corresponding author)

rachel.jakhelln@uit.no

https://orcid.org/0000-0002-9313-2082

\section{Gunilla Eklund,}

Faculty of Education and Welfare studies, Åbo Akademi university, Finland.

Faculty of Education and International Studies, Oslo Metropolitan University, Norway

geklund@abo.fi

https://orcid.org/0000-0003-1876-1441

\section{Jessica Aspfors,}

Faculty of Education and Arts, Nord University, Norway

Faculty of Education and Welfare studies, Åbo Akademi university, Finland

Jessica.m.aspfors@nord.no

https://orcid.org/0000-0002-1865-6302

\section{Kristin W. Bjørndal,}

Department of Education, The Arctic University of Norway, Norway

Kristin.e.bjorndal@uit.no

\section{Gerd Stølen,}

Department of Education, The Arctic University of Norway, Norway

Gerd.stolen@uit.no 


\begin{abstract}
This study examines newly qualified teachers' (NQTs) understandings of research-based teacher education practices by looking at two cases in Finland and Norway. The NQTs were interviewed after they had finished their master's degrees and before they started their careers. The results of the individual semistructured interviews and a thematic analysis revealed a weak connection between research-based knowledge gained from initial teacher education (ITE) and the teachers' professional work. The Finnish NQTs were highly research oriented, while the Norwegian NQTs focused on teachers' development of their daily work. The results are discussed in relation to the theory of practice architectures, as well as how cultural-discursive, material-economic and social-political arrangements enable and constrain different kinds of research-based ITE practices in both countries.
\end{abstract}

Keywords: Newly qualified teachers, research-based teacher education, practice architectures, teacher education practices, 


\section{Introduction}

International educational trends, students' outcomes and the traditional tension between theory and practice in initial teacher education (ITE) have resulted in research for better solutions and continuous development of teacher education (Haug, 2010). The report entitled Teachers Matter (Organisation for Economic Cooperation and Development [OECD], 2005), which focuses on teachers' impact on students' achievement, argued for the importance of strengthening ITE in general and teachers' research-based competence. Since then, to ensure that teachers' learning and professional development are taken into account throughout their careers, research has focused on the discourse about ITE (cf. Day, 2007). After the turn of the millennium, there has been a range of perspectives on ITE quality; for example, the British Education Research Association - The Royal Society for the Encouragement for the Arts, Manufacturing and Commerce's (BERA-RSA) (2014) report concluded that full integration of theory and practice and a strong inquiry orientation represent ITE best practices.

Finnish teacher education has been research-based for decades and is inspiring educational development in other countries because of its strong system (Darling-Hammond, 2017). It has undergone very few reforms since the 1970s and is characterised by conventional ideas, forms and stability. However, the research-based approach and the relation between theory and practice are topics of ongoing discussion (cf. Hansén, Forsman, Aspfors, \& Bendtsen, 2012; Hökkä \& Eteläpelto, 2014; Jakku-Sihvonen \& Niemi, 2006; Malinen, Väisänen, \& Savolainen, 2012; Toom \& Husu, 2012).

For many years, Norwegian teacher education has been characterised by a gap between theory and practice (the Norwegian Agency for Quality Assurance in Education [NOKUT], 2006; Trippestad, Swennen, \& Werler, 2017). It has undergone a series of reforms over the last decades, changing from broader, more practice-based ITE to a professional education provided at the master's level. The previous decades' changes from an experience-based tradition to a stronger focus on research and practice development can be understood as a paradigm shift (Stølen, 2016) under Finnish inspiration (Afdal \& Nerland, 2014; Lillejord \& Børte, 2017). This shift has been implemented through two reforms, first in 2010 with a stronger focus on indepth knowledge and research and development (R\&D) and later in 2017 with a change from a 4-year programme at the bachelor's level to a 5-year master's programme. According to the latest national curriculum plan, the new programmes at the master's level prepare student teachers for continuing professional development and are based on the student teachers' knowledge of scientific theories and methods (Ministry of Education and Research, 2016a, 2016b).

Consequently, Finnish and Norwegian teacher education are both research-based yet differ in their reform pace, design, focus and understanding of the underlying approach. It is thus relevant and interesting to compare these two research-based teacher educations, one with 40 years of experience and one which recently has undergone radical changes. The current comparative case study (cf. Blömeke \& Paine, 2008) addresses the issue of research-based teacher education and how it is framed by national policies and trends and understood by NQTs from two sites: the teacher education programme at Åbo Akademi University ( $\mathrm{A}$ ) in Finland 
and a pilot program at the master's level at the Arctic University of Norway (UiT). The study draws on the theory of practice architectures (Kemmis \& Grootenboer, 2008) and on theory about research-based education (Griffiths, 2004), with the aim of examining NQTs' understanding of research-based teacher education practices in two cases in Finland and Norway. The study poses the following research questions:

1. What understandings of research-based teacher education is prevalent among NQTs in the Finnish and the Norwegian sites under examination?

2. How do cultural-discursive, material-economic and social-political arrangements prefigure, enable and constrain different kinds of practices and understandings of research-based teacher education among NQTs?

\section{Theoretical background}

\section{Understanding research-based teacher education through the theory of practice architectures}

To gain a better understanding of research-based teacher education practices, the theory of practice architectures is used as a lens (Kemmis \& Grootenboer, 2008). This theory emphasises practices as social phenomena and draws attention to three kinds of intersubjective spaces where the participants in teacher education practices (politicians, teacher educators, student teachers, etc.) encounter one another through language and through space-time in the material world and in social relationships. These spaces (sayings, doings and relatings) "hang together" for a particular purpose, which in this theory is called a project of a practice (Kemmis, Heikkinen, Fransson, Aspfors, \& Edwards-Groves, 2014, p. 4). An example of a project is the development of ITE in Norway with a strong focus on academic skills and in-depth knowledge at the master's level. However, these practices do not occur in a vacuum but are instead held in place and shaped by prevalent arrangements at specific sites. To understand teacher education, one must pay attention to 'how it unfolds and takes shape as a practice in particular sites and particular times (Heikkinen, Wilkinson, Aspfors \& Bristol, 2018, p. 2).

In the dimension of semantic space, the participants' language is enabled and constrained by the cultural-discursive arrangements of specific teacher education practices (cf. Heikkinen et al., 2018). In relation to the dimension of physical space-time, teachers' activities are enabled and constrained by the material-economic arrangements in the world, specifically in how things are done. For example, different kinds of physical arrangements, as whether the teacher education is organised at a university or school, shape and make possible particular kinds of teacher education practices. Finally, regarding social relationships in the dimension of social space, teachers are enabled and constrained by the social-political arrangements, specifically in how people relate with one another in the medium of solidarity and power (Kemmis, Wilkinson, Edwards-Groves, Hardy, Grootenboer, \& Bristol, 2014).

Thus, the theory of practice architectures enables deep insight into the understanding of research-based teacher education practices in the two study sites of Åbo Akademi University 
and the Arctic University of Norway. In the following, we outline a brief background of research-based teacher education and its characteristics.

\section{Research-based teacher education}

The research base for teacher education is still criticised for being narrow and fragmented (Özçınar, 2015). Numerous studies have reported on the weak impact of teacher education on teachers' prior beliefs and attitudes when teachers start working in the profession (cf. Brouwer $\&$ Korthagen, 2005). Critics have advocated for the necessity of real-world experiences and a tighter connection between courses and field experiences (Fletcher, Chang, \& Kong, 2008). Previous research has shown that most NQTs feel they are not sufficiently qualified for the demands of their work (Bezzina, 2007). This is especially the case if teacher education is highly research-based and scientific; teachers may then find it difficult to apply research-based knowledge in practice (cf. Hansén, Eklund, \& Sjöberg, 2015).

Debates on teacher education tend to focus on organizational aspects of programmes. According to Zeichner (2014), two strategies for designing ITE programmes have been in the forefront: to strengthen the dominant university-based system of ITE or promote greater deregulation and privatisation, with shorter teacher training routes offered mainly in schools. Today, both Finland and Norway follow the first strategy.

In accordance with a university-based ITE system, research plays a crucial role. Concepts such as inquiry-oriented, research-informed and research-based are used interchangeably in the literature, and distinctions among them are not always obvious (Burn \& Mutton, 2015; Cochran-Smith \& Fries, 2008; Munthe \& Rogne, 2015). According to the research-teaching nexus, Griffiths (2004) attached four characteristics of teaching in education programmes: research-led, where the curriculum is structured around subject content and understandings of research findings; research-oriented, referring to providing an understanding of research processes and the results of the research; research-based, pointing to curriculum designed around inquiry-based activities; and a focus on systematic inquiry into teaching and learning itself. Griffiths further (2004, p. 723) argued that there are tensions between 'those elements in the curriculum that are concerned with "research-facing" forms of investigative activity and those concerned with more "practice-facing" forms of inquiry'.

According to Stenhouse's (1975) ideas about teachers as researchers, teachers should undertake a systematic inquiry in their own classrooms and be able to identify, investigate, criticise and change their practice and share their insights with other professionals. Similarly, BERA-RSA (2014) concluded that teachers and teacher educators should be equipped to engage in inquiryoriented practice; this is understood as the capacity to investigate what works well and what is not fully effective in one's own practice (cf. Toom et al., 2010, p. 339). Thus, research-based teacher education should focus on research not only about the school, but also in school (cf. Sandén \& Wikman, 2010). The concept of research-based is adopted and used in both Finland and Norway, although with slightly different meanings. 


\section{Case descriptions}

\section{The teacher education context of the Finnish case}

Teacher education for primary school teachers is offered at eight universities in Finland; two of these schools offer Swedish-speaking programmes. Åbo Akademi University has offered Swedish-speaking teacher education since the 1970s, while the corresponding programme at Helsinki University started in 2016. The main subject in primary school teacher education (teachers of 6-12-year-old children) is education (140 European Credit Transfer and Accumulation System, ECTS), and in relation to the broader European context, this is quite exceptional (Jakku-Sihvonen, Tissar, Ots, \& Uusiautti, 2012). Student teachers gain insights into areas such as general didactics, educational psychology, educational philosophy and educational sociology, and they further write their bachelor's and master's theses about education. After completing their master's degrees, they can apply for postgraduate studies in education. Student teachers also acquire broad competence in all subjects taught in primary schools and usually choose to specialise in one or two subjects (Hansén \& Eklund, 2014; Niemi \& Jakku-Sihvonen, 2011). Practice-oriented activities (20 ECTS) are mainly organised in government-operated teacher schools and - only to some extent - in ordinary field schools. With a strong tradition in tripartite collaboration among lecturers in the government-operated teacher school, lecturers in the faculty of education and student teachers (cf. Jakku-Sihvonen \& Niemi, 2006a), this system ideally allows for a stable collaboration between theory and practice (Toom et al., 2010).

Teacher educators are research qualified, and their teaching is research-based. Student teachers are encouraged to develop critical thinking and to reflect on the aspects related to the essence of their profession. Thus, a research-based approach implicitly characterises their education (Afdal, 2012a; Jakku-Sihvonen \& Niemi, 2006; Kansanen, 2014). Student teachers become familiar with scientific research, write scientific texts and take specific research methodology courses. Furthermore, they carry out their own research projects for their bachelor's and master's theses, use scholarly methods and gain insights into data collection methods, systematic analytical thinking, interpretation and evaluation. Consequently, a research-based approach is also explicit in their teacher education (Hansén et al., 2015). The research-based approach is thus essential for teacher education although the challenge is to balance researchoriented activities to promote the student teachers' professional development in both short and long terms (cf. Sjølie, 2014).

\section{The teacher education context of the Norwegian case}

Having undergone six reforms since the mid-1970s - with the latest one being launched in 2017 - Norwegian teacher education is marked by changes (Trippestad et al., 2017). Over the same period, the higher education system has undergone numerous mergers; 11 institutions currently offer ITE. When knowledge about the implications of an R\&D-based ITE for teachers' status and development of teaching quality is in demand, it is meaningful to investigate existing 
examples. In 2010, UiT launched a national pilot programme in ITE called Pilot in North (PiN). This was the first Norwegian 5-year integrated R\&D-based programme in ITE for primary and lower secondary school teachers. Consequently, it is of interest to study the results of this programme because no one has yet graduated from the reformed ITE from 2017, and this new programme builds on the main principles of PiN.

Similar to PiN, the latest reform of the teacher education programmes from 2017 onwards is intended to have high academic quality and ensure comprehensiveness and coherence among subjects, subject didactics, education and practice placement, as well as close interactions with professional practice and the communities where the field schools belong. Education covers general theories of learning and understanding of students, in addition to offering knowledge about schools and organizational development. The ITE is differentiated into two programmes adjusted to the Norwegian educational system: 1st-7th and 5th-10th grades (the Norwegian Ministry of Education and Research, 2016a, 2016b) (from here ITE 1-7 and ITE 5-10). In ITE 1-7, student teachers take 60 ECTS in education and three or four school-related subjects, among them math and the Norwegian language. In ITE 5-10, student teachers take 60 ECTS in education and two or three school-related subjects (150 ECTS in the main subject). The master's thesis focuses on education, special education or subject didactics, and student teachers can apply for postgraduate studies in education afterwards. PiN has had the same design, though the master's thesis for ITE 1-7 has been written in education and subject didactics for ITE 510. The practice placement should comprise at least 110 days of supervised, varied and assessed practice (PiN 120 days). The teacher education institutions have partnership agreements with schools, and mentoring courses with at least 15 ECTS are required for the mentors in the schools. The vision of the new ITE is to cultivate a teacher identity marked by an inquiring attitude towards teaching.

\section{Method and analysis}

\section{Research design}

To answer the research questions, we chose a qualitative and comparative research approach. A comparative design encourages making the familiar strange by using a contrasting mode, which enables a closer look at contextual features, knowledge structures, systems and beliefs (Blömeke \& Paine, 2008). Semistructured interviews are used in the data collection, which is considered a typical methodological framework within the constructivist research paradigm (Hatch, 2002).

\section{Participants and data collection}

The data were collected from two cases - Åbo Akademi University ( $\AA$ A) in Finland and UiT (PiN) in Norway - by a Finnish and a Norwegian research team, respectively. Å was chosen as a case for the current study because it is the only university in Finland that has been educating 
Swedish-speaking primary school teachers for decades in contrast to the other programme at Helsinki University, which only began in 2016. UiT was chosen as the Norwegian case because the new national programme (2017) builds on the experiences from PiN. Altogether, 42 NQTs participated in individual semistructured interviews directly after finishing their master's degrees and before most of them began working as teachers. The study was based on a selection of informants who have strategic qualifications based on the issue (Thagaard, 2006). The selection was carried out through self-selection after a written invitation containing a thorough description of the study.

In Finland, about 50 teachers who graduated in the 2015-2016 school year were invited to participate in the study; in total, 18 agreed to be interviewed (two males and 16 females). The NQTs were all educated as primary school teachers. The two Finnish researchers and a research assistant held the interviews at the university or online in 2016. In Norway, 12 of the informants were interviewed in the spring of 2016, and this was followed by an additional 12 in the spring of 2017. The Norwegian sample, which comprised seven males and 17 females, were educated as primary and lower secondary school teachers. Three Norwegian researchers and two research assistants conducted the interviews at the university or online.

The Norwegian research team developed the interview guide. A pilot study in 2015 involved 24 teachers from the first cohort at UiT before the instrument was finalised. One pilot interview was also conducted to test the guide in the Finnish case. The interview guide comprised five main themes concerning a) teachers' background characteristics; b) teacher education design regarding the subjects, subject didactics, practicum placement and education; c) teachers' experiences with research-based teacher education in general; d) research methods, specifically thesis work; and e) the visions of the teachers' professional futures. In relation to each theme, four to seven interview questions were asked, and when appropriate, follow-up questions were prompted. For the purpose of the current article, the focus was on theme d. The questions included the following: What did you write about in your master's thesis, and why did you choose that theme? What has your work on your master's thesis given you in relation to the development of your professional knowledge? What is the importance of research-based education for the teacher's work?

The interviews from both Finland and Norway lasted about 60 minutes each. All interviews were audio recorded and transcribed verbatim. The present study follows the general ethical standards approved by the scientific communities in the two countries: the Finnish Advisory Board on Research Integrity (2016) and the Norwegian National Research Ethics Committees (2016).

\section{Data analysis}

The analysis process was based on a thematic analytical approach. Both the Finnish and Norwegian researchers organised their analyses in six phases, which are inspired by Braun and Clarke (2006) (Table 1). 
[Table 1. Near here]

Intensive dialogues between the Finnish and the Norwegian researchers were held throughout the writing process, and this lasted for 2 years. The researchers had face-to-face meetings four times and teleconferences in between. This communication was important to ensure a common understanding of the focus of the current article, the analytical process and the findings in relation to the two different cases.

\section{Results}

The first research question guided the analysis of the NQTs' understanding of research-based teacher education in the Finnish and the Norwegian sites. The analysis revealed five and four main categories, respectively, together with specific characteristics of each identified category. This section presents illustrative quotes from the interviews with the NQTs (FT = Finnish teachers, NT $=$ Norwegian teachers). The authors translated the Swedish and Norwegian responses into English.

\section{NQTS' understanding of research-based teacher education at the Finnish site}

The Finnish NQTs' knowledge gained from teacher education was specifically related to research competence. Five categories were found: knowledge of previous research, research methodology, scientific theses, research topic and critical thinking and understanding.

\section{Knowledge of previous research}

The NQTs $(\mathrm{N}=10)$ explained that during their education, they acquired knowledge of previous research. Teacher educators are research qualified and expected to base their teaching on research, which the NQTs viewed as positive: 'Yes, of course, we read scientific articles, and I believe it belongs to research, but ... then, some teachers now and then do some investigations themselves ... I just take it as a natural part of the university somehow' (FT-7). During their courses, the student teachers read scientific articles and learned to analyse and reflect on relevant pedagogical issues. The NQTs experienced the research-based approach as more obvious in the theoretical courses than in practice. Although they found research and different kinds of investigations to be mostly theoretical, some of them could relate research to practice and their own practical teaching.

\section{Research methodology}

Almost all the NQTs $(\mathrm{N}=15)$ emphasised the knowledge and insights they gained about research methodology, particularly at the master's level. Generally, they understood the structure of a scientific thesis and how to construct a thesis themselves. Specifically, they pointed out knowledge of various data collection methods, such as interviews and statistical 
methods. By taking the research method courses and by doing their own research projects, they increased their competence in research methodology. However, this research methodology was explicitly seen in a conventional way and not experienced as a tool for carrying out developmental projects in schools outside university. Some NQTs noted that they learned about searching for information and being critical of various kinds of sources; however, others mentioned something closer to the following: '... and then you also get the ability ... there is no chance to learn everything you need over 5 years, but I still gained knowledge about how I can find information that I want so that I can learn on my own. That is what is most important to know, how you can find reliable information that you can then ... well, so that you can learn everything you want to know' (FT-6).

\section{Scientific theses}

Because student teachers write their master's theses during the final year of their education, most of the NQTs $(\mathrm{N}=13)$ focused on their theses. They pointed out that they learned how to plan and carry out a research project from the beginning to the end, and they acquired practical tools for this work. They also obtained knowledge of a certain problem or challenge and became better researchers, as follows: 'When I hear research, I immediately think of the bachelor's and the master's theses... and of course, knowledge about how a thesis is constructed and things like that, you get automatically' (FT-7). Most of the NQTs had trouble with writing a thesis, but as time passed, they learned more, and it felt easier to write one. Some of them also highlighted that writing a scientific thesis was a challenging but rewarding process, and in the end, they were proud of their finished theses. However, most NQTs could not recognise the relationship between writing a scientific thesis and teacher work or projects in the teacher profession, while some explained that their theses had partly influenced school and society in general sense.

\section{Research topic}

Almost all the NQTs $(\mathrm{N}=17)$ were deeply involved in the research process and developed a lot of knowledge about their topics, such as teaching immigrants, conflict management, cyberbullying, language learning and motivation. Obviously, they conceived of these topics as mainly relevant to a master's thesis, and some of them could relate their theses to their future teaching profession. They became more interested in their chosen topics and in applying their knowledge and insights in their future teacher profession: 'You have also gained a lot more knowledge about the subject you have written about... In my bachelor's thesis, I wrote about how teachers can support children of divorced parents. It is something I will later encounter in school...' (FT-6). However, the NQTs did not see the topics as points of departure for developmental projects in the schools, and most of them had trouble recognising the relevance of their theses to society in general. Only one NQT was interviewed in the press and on the radio about her thesis, while the others only presented their theses during the final research seminars. 


\section{Critical thinking and understanding}

Most of the NQTs $(\mathrm{N}=11)$ developed and furthered their scientific thinking and understanding during the research process. They explained that they cracked the research code and developed their own way of thinking. They became more reflective and learned to be more critical and question established research results: 'Maybe, an understanding of how researchers reach results or how they obtain them, maybe, it offers a chance to question the results a bit, being critical. Now, it is like this, and research says this, but one can maybe think of these factors as well. It is not a question of black or white' (FT-7). Some also related their scientific thinking and understanding to their future profession. They knew how to find reliable knowledge and facts based on research and could handle these facts and knowledge in a critical and reflective way. Some also perceived the relationship between theory and practice and understood the relevance of research to their everyday job. They understood how research can facilitate their teaching and learned to take a critical stand. However, although the NQTs had developed a better understanding of research, the relationship between research and school development was not obvious to them.

\section{NQTs' understanding of research-based teacher education at the Norwegian site}

In the Norwegian data, four main categories emerged from the analysis: development of everyday practice, professional and personal development, $R \& D$ - tools for teachers and ambivalence about the benefit of $R \& D$ competence. The whole cohort communicates an understanding of ITE as professional education that has the purpose of creating a developmentoriented professional attitude, which could be done by focusing on change and development in the teachers' daily work.

\section{Development of everyday practice}

All the interviewed NQTs $(\mathrm{N}=24)$ talked about the development of everyday practice. Organisational change and development $(\mathrm{N}=19)$ and an understanding of $\mathrm{R} \& \mathrm{D}$ as $a$ foundation to initiate change and development $(\mathrm{N}=8)$ were the focus. The NQTs found $\mathrm{R} \& \mathrm{D}$ meaningful for developing teachers' everyday practice; here, the NQTs understood R\&D as a set of new actions to deal with different challenges and increase the quality of teaching. A smaller group of NQTs viewed change and development as liberating, considering these would not just be ideas about immediate reactions to upcoming situations in class or among colleagues. The focus on development had its foundation in an understanding of knowledge-based professional work and - for some - in action research and action learning. This concept is linked to the teachers' continuing professional learning, a life-long learning perspective: '... if I reflect on what worked and eventually did not work, I can develop as a teacher and communicator and increasingly learn through my own practice' (NT-49). In sum, the teachers regarded reflection and learning as part of the daily work of teachers.

\section{Professional and personal development}


Many of the NQTs talked about personal development $(\mathrm{N}=17)$. Some perceived the focus on change and development in ITE as a foundation for personal and professional development $(\mathrm{N}$ = 10); others talked about teachers as researchers in their own practice $(\mathrm{N}=7)$. Most mentioned both change and development, questioning the fact that the everyday work seemed to be part of their professional habitus, as one NQT demonstrated: 'Just that you think about what you have done: "What could have been done in another way?", "Is it something I should have changed?" "Shall I continue with this?" "How long shall I do it like this before I change my actions?" You understand - You have to look at yourself as a researcher but also use it on the students and teach the students to think as researchers. I think that this sort of thinking is implemented in me after these five years. It is how professionals work' (NT-38). The NQTs showed a reflective attitude towards a teacher's work, not a systematic initiative to change their own teaching or organisational structures.

Several of the NQTs mentioned critical thinking $(\mathrm{N}=11)$. The way that they understood critical thinking was related to the teachers' practice and - to a lesser degree - to research. Having a critical examination of their own practice and judging it from a distance, which involves time, research knowledge or collegial dialogues, was valued as a professional approach $(\mathrm{N}=11)$. It was described as developing a critical eye, taking a step back or questioning what is happening in the organisation. The metaphor of having a critical eye was also used in the programme plan of study, which explains why most of the NQTs mentioned it. A critical eye was linked to both developmental understanding of the work and research and was understood as a starting point for initiating change and a premise for professional work. The NQTs were aware of the new reforms in teacher education and the focus renewing the teacher's role as a more knowledgebased and professional practice.

\section{$R \& D-$ Tools for teachers}

Most of the NQTs demonstrated a technical or instrumental understanding of R\&D and understood it more as a tool: 'First and foremost, it is $R \& D$ that has given us the wish to develop our own work. When I am in school, I feel like trying out things, new ideas and innovations and implementing these in school. To think and to look at your classroom with a researcher's eye when different situations arise' (NT-30). Nine NQTs explicitly mentioned research as having an academic and professional quality; they understood research as a tool related to methods of data collection and systematic analyses of actual practice. NT-47 said, 'You relate your work to research and not just to traditions'. Two of these nine NQTs found it meaningful '... to go deeper into a topic' (NT-28 and NT-30) and related it to their work on the master's thesis. Several NQTs focused on the research topic of the master's thesis and found it meaningful for their future work in school. For example, NT-46 wrote about exploratory mathematics, while NT-43's thesis topic was fast literacy. The nine NQTs who explicitly mentioned research perceived the teachers' job as research-based professional work. 
According to their R\&D competence, six of the NQTs demonstrated ambivalence regarding the transition from study to work; they were afraid of settling into fixed patterns but were insecure about the possibilities of using research systematically because of the pressure of time. Some NQTs seemed to have negative expectations of teachers' time-consuming work and did not see how it could be possible to engage in research-based work early in their careers, as follows: ' $I$ do not think there will be so much room to work with $R \& D$-based development' (NT-28). Others demonstrated their ambivalence towards R\&D, as NT-29 admitted, 'Sometimes, I am so bored of it [R\&D]. "Why do they focus so strongly on this? I shall not become a researcher". But then I think that it will increase my critical attitude and my ability to seek new knowledge and cooperate with different specialist environments and learn more!' The ambivalence among the NQTs demonstrated an interpretation of a difference between a traditional understanding of research and a research-based teacher practice, which could be seen as rewarding.

\section{Discussion}

\section{The differing understandings among the Finnish and Norwegian NQTS}

The first research question focused on the NQTs' understanding of research-based teacher education in the Finnish and Norwegian sites. The results revealed different experiences and understandings among the NQTs. The Finnish NQTs understood their ITE as highly research oriented; they appreciated their education and understood it as a solid basis for the profession. The Norwegian NQTs seemed more engaged in the teachers' daily work and the development of their profession. Thus, Finnish teacher education is more strongly focused on research as an academic practice compared with the Norwegian one. Both the Finnish and the Norwegian results demonstrated that the connection between research-based knowledge in ITE and teachers' professional work is continuously challenging. The Norwegian NQTs showed an ambivalence between R\&D-based knowledge gained from ITE and the possibilities to draw on this knowledge in their future work. In contrast, the Finnish NQTs seemed to take for granted the 5-year teacher education without questioning its relevance to the profession.

\section{Practice architectures of teacher education in Finland and Norway}

To answer the second research question, the following subsections explicitly relate the results of the two cases to the theory of practice architectures, as well as how cultural-discursive, material-economic and social-political arrangements prefigure, enable and constrain the practices and understandings of research-based teacher education.

Although both Finland and Norway follow the university-based strategy (cf. Zeichner, 2014), the different study designs at the two sites have resulted in varying understandings of the research-based concept. The aim at both sites is to educate teachers who are ready to develop and change their teaching practice based on educational research. The focus on development, which is an integrated part of the concept of research-based teacher education in Norway, is 
excluded from the Finnish concept. Thus, the two practices have different kinds of projects (cf. Kemmis \& Grootenboer, 2008). To capture the conditions and underlying arrangements that underpin these differences, the current study portrays the practice architectures of the two teacher education practices.

\section{Cultural-discursive arrangements}

In relation to language, in the semantic space, the NQTs are enabled and constrained by the cultural-discursive arrangements of specific teacher education practices. According to these arrangements, the following discussion identifies some aspects related to the traditions, knowledge base and academic language at the national level in the two countries.

The results revealed that the NQTs in the Finnish case primarily emphasised the explicit aspects of research-based teacher education in terms of knowledge of previous research, research methodology and a scientific thesis and topic. The implicit aspects became more obvious in the NQTs' critical thinking and understanding (cf. Hökkä \& Eteläpelto, 2014; Krokfors et al., 2011; Kynäslahti et al., 2006; Tryggvason, 2009). In Finland, teacher education, as well as education in general, has played an important role in developing the modern welfare society, where, since after World War II, school teachers have been perceived as 'nation builders' (cf. Koskenniemi \& Hälinen, 1970; Lahdes, 1969; Rinne, 1984). The academisation of teacher education in the 1970s was implemented during a time of progressivism (cf. Tirri, 2014; Toom et al., 2010). Today, teachers still perform an important function in society, and there is a positive circle of recognition, maintaining a positive discourse on the teacher education profession (cf. Heikkinen, Jokinen, \& Tynjälä, 2012). Furthermore, the NQTs in the current study conceived of teacher education as a stable foundation for the profession (cf. Aspfors \& Eklund, 2017).

Compared with Finland, the academisation of Norwegian teacher education is new. The aim of the previous general professional programme (until 2010) was to educate teachers who understand the practice of teaching in the ongoing context and hold the logics of practice, that is, what works (Afdal, 2012b). With its focus on R\&D, PiN has been a change from contextual to more conceptual teacher education (Afdal \& Nerland, 2014; Muller, 2009), and this approach has been confirmed in the most recent reform in 2017. In the present study, the Norwegian NQTs' ambivalence towards the use of R\&D early in their careers may indicate that their teacher education has not diminished the traditional tension between contextual and conceptual knowledge in the teacher profession. On the other hand, the Norwegian results demonstrated a strong focus on professional and personal development, and the NQTs emphasised a critical attitude as part of a teacher's habitus; they understood teachers' work as a continuous search for improvement of everyday practice.

As a result of the two traditions characterising the practices of the Finnish and the Norwegian sites, differences in the professional language used among the teachers can be recognised. Discourses on research-based education and academic language in Finland have been well established and characterise the profession, a theme that emerged among the NQTs through critical thinking and reflection. The language used by Finnish teachers is thus characterised by 
conceptual coherence, whereas in Norway, the language is - to a larger extent - characterised by contextual coherence (cf. Afdal \& Nerland, 2014; Jakhelln, Bjørndal, \& Stølen, 2016; Muller 2009). The strong focus on everyday practice, demonstrated in our study, provides an example of this situation. Moreover, the content of the eduction-subject varies between the two countries, Finland has a more theoretical focus compared to Norway's more practical and contextual focus.

\section{Material-economic arrangements}

In relation to space-time in the material world, teachers are enabled and constrained by the material-economic arrangements that enable and constrain how tasks are performed. According to these arrangements, two relevant aspects - an economic approach to practice and how teacher education is designed - are identified on the national level and discussed in relation to our results.

According to the Norwegian results, the NQTs first and foremost focused on a teacher's own development and the students' learning and welfare, but the contribution for society was not mentioned. Since the late 1980s, the Norwegian school system, including teacher education, has been influenced by human capital theories and new public management governance, involving market mechanisms and a comparison of consumer choices in policy-making (Karlsen, 2014; Trippestad et al., 2017). In Norway, the government systematically offers economic incentives to strengthen a research-based perspective in teacher education and the students' results. The Norwegian data from the current study demonstrated an understanding of R\&D-based knowledge as a tool for the teachers to analyse and improve their own practice. On the other hand, the NQTs see teachers' time-consuming (overwhelming) workload as a hindrance for systematic improvement and innovation, which can be understood as a mismatch between the material-economic arrangements and the perceived possibilities.

Finland has demonstrated another way of building a high-performing education system by using solutions that differ from market-driven education policies. Sahlberg (2011) pointed out that this does not mean that elements of accountability are completely absent in the Finnish educational system, but 'perhaps, it does imply that a good education system can be created using alternative policies orthogonal to those commonly found and promoted in global education policy markets' (p. 102). According to Darling-Hammond (2006) and Sahlberg (2011), the systematic nature of research-based teacher education curricula is the key strength and characteristic that distinguishes Finnish teacher education from those of many other nations. In the current study, the Finnish NQTs expressed a strong research-based approach that had been developed from their teacher education. When relating to this education, writing the master's thesis was seen as being at the forefront; for example, the choice of topic and the comprehensive writing process were emphasised. However, it was evident that the NQTs were not so convinced about how the explicit aspects of the research-based approach could be used concretely and creatively in the teaching profession. Over the last few years, Finnish teacher education has met economic challenges, and new forms of financing have been launched. The research-based approach is nevertheless still reinforced, and student teachers should learn how to assimilate an inquiry-based and creative approach into their future profession. 
Referring to the first characteristic of a research-based teacher education approach (Griffith, 2004; Kansanen, 2014), research-led relies on well-proven experience. The structural and competence-based prerequisites for the other three criteria, research-oriented, research-based and research-informed, are met by Finnish teacher education institutions because teacher education requires fully academic institutions, research-qualified staff and the expectations for conducting research. In the present study, the NQTs assumed that research-based teaching is a natural part of education at the master's level, and they appreciated it. After its latest reforms in 2010 and 2017, similar expectations were placed on Norwegian teacher education. R\&D has an integrating dimension in Norwegian ITE programmes as a strategy to strengthen the professional profile of the teaching profession and connect the coursework with professional actions in school (Rindal, Lund, \& Jakhelln, 2015). On the whole, the Norwegian results demonstrated that $R \& D$ was seen as a foundation for more development of the teacher's own work.

\section{Social-political arrangements}

In relation to social relationships in the medium of solidarity and power, teachers can be enabled or constrained by the social-political arrangements in the social space, influencing how people relate with one another. According to the social-political arrangements, three crucial aspects are identified on the national level: autonomy, power and policy.

The Norwegian teacher education programmes should prepare student teachers for continuing professional development based on their knowledge of scientific theories and methods, as well as develop their R\&D skills (Ministry of Education and Research, 2016a, 2016b). Though the Norwegian NQTs viewed R\&D as a tool for change and development, the majority did not demonstrate a deeper understanding of the implications of R\&D-based knowledge for a teachers' work. The results were unsurprising, especially considering the situation of a new teacher education reform, large variations related to the teacher educators' backgrounds and weak definitions of central concepts in ITE. Despite the R\&D focus of Norwegian teacher education since 2010, it has varied considerably in both context and content (Munthe \& Rogne, 2015). The R\&D concept is weakly defined in actual policy documents, with little knowledge of how the R\&D focus has influenced Norwegian ITE and schools. The OECD and comparisons among countries are setting the agenda in Norwegian educational policy. The past few years have been characterised by an extended tendency to seek other countries' models and designs to be implemented through reform policies (cf. Karlsen, 2014; Møller, 2017). According to Trippestad et al. (2017), the late 1990s witnessed a change in governance ideology from plan regimes to reform regimes. Similar to many other European countries, poor school quality and pupil performance have been associated with the failure of teacher education (Trippestad et al., 2017). The ambivalence about the significance of the Norwegian NQTs' R\&D competence can also be interpreted as a result of this situation.

In the present study, the Finnish NQTs noted that the master's thesis is a challenging but rewarding part of teacher education; they appreciated the research-based approach, and despite experiencing it as somewhat challenging, they recognised its value for a teacher's work. Compared with those of other Nordic countries, teacher education in Finland has undergone 
few reforms and is rather stable (cf. Aspfors, Hansén, \& Ray, 2013; Jakku-Sihvonen \& Niemi, 2006). Educational autonomy is highly valued at all levels, and quality assurance is based on steering instead of controlling. The system highly relies on the proficiency of teachers and other personnel (cf. Aspfors, Eklund, Hansén, \& Wikman, 2018). As a result, teaching in Finland is a respected profession, and teachers have enjoyed a high status and authority in the public (OECD, 2013). Teachers exercise substantial pedagogical autonomy; for example, they can determine their own teaching methods, textbooks and other learning materials. National examination tests do not exist, and teachers have full responsibility to evaluate and examine their pupils' knowledge.

To a greater extent, Norwegian teachers are controlled by national regulations, though with the teachers focusing on their own teaching, classroom management and themselves as leaders in the classroom (Lillejord \& Børte, 2017). The professionalisation of teacher education and the teachers' work is in the forefront in Norway (Mausethagen, 2015) and is an ongoing task. The latest reform aims to raise the status and quality of the teachers' work, and the master's education for teachers has been perceived as a tool for this development. Only a few of the NQTs in the Norwegian case viewed the master's thesis as contributing to knowledge in the field of teaching. However, the reformed teacher education implies a potential for teachers to play a role as producers of knowledge that is meaningful for their profession.

\section{Strengths and weaknesses}

The researchers in the current study had different roles and positions. Three of the researchers were working as teacher educators at the departments chosen to study, while the other two were not involved in the actual programmes. In addition, three research assistants conducted half of the interviews. Because the informants were already qualified as teachers, no direct power relations existed at the time when the data were collected. Conscious efforts were, nevertheless, made to reduce possible ethical dilemmas. The NQTs were encouraged to be honest about their understandings, to support further development of the teacher education.

The comparative approach highlights the similarities and differences between the two sites and shows the visible characteristics that are implicit and often taken for granted. Consequently, the comparative approach also enables more profound insights into the respective case (cf. Blömeke \& Paine, 2008). However, the purpose of the investigation has not been to provide generalisable answers, but instead make the current study relevant and useful to the reader because this research can act as a mindset and a development tool for the reader's own practice (cf. naturalistic generalisation by Stake \& Trumbull, 1982).

\section{Conclusions}

Drawing on the theory of practice architectures (Kemmis \& Grootenboer, 2008) and on research-based teacher education theories (Griffiths, 2004), the aim of the current study was to gain a deeper understanding of research-based teacher education practices among NQTs in 
Norway and Finland. The Finnish NQTs understood their ITE as highly research-oriented; they appreciated their education despite finding the connection between research-based knowledge and teachers' professional work challenging. Their understandings can mainly be related to the cultural-discursive arrangements in terms of a long research-based tradition and wellestablished academic language in teacher education and among teachers in the field. Despite economic difficulties, the design of teacher education in Finland has remained stable and retains its high academic level, referring to the concept of material-economic arrangements. Similarly, the social-political arrangements (e.g., few reforms and a limited policy-driven approach) have led to a strong, autonomous and decentralised teacher education and profession.

The discussion on cultural-discursive arrangements has shown that Norwegian teacher education has undergone a paradigm shift. The results indicate that the way in which the field of practice perceives teachers' work does not correspond with how the ITE presents teachers' work. This was demonstrated in the ambivalence present in the Norwegian results. This twofold reality, which the students experienced during their teacher education, will probably influence their understanding of the research-based role and work of teachers. The dominating policy-driven approach of the reforms in Norwegian teacher education has led to a contradictory situation. On the one hand, the reformed ITE involves a policy-driven focus on professionalisation and teacher education emphasising research-based developmental competence. On the other hand, the governmental focus is on steering and control of the practice in the field. These contradictions, which were mirrored in the results and theoretical discussion, are challenging for Norwegian NQTs, schools and teacher education.

In conclusion, developing teacher education as a research-based teacher education practice requires changes in the practice architectures that support and make it possible. However, the results of the efforts for change and development also depend on how the school community accepts the research-based approach, both in Finland and Norway, and how the new teachers' competence is taken into account in the workplace. To enhance the development of teacher education, further research on the understanding of research-based ITE among school teachers and teacher educators should be conducted.

\section{References}

Afdal, W. H. (2012a). Constructing knowledge for the teaching profession. A comparative analysis of policy making, curricula content, and novice teachers' knowledge relations in the cases of Finland and Norway (Unpublished doctoral dissertation). Faculty of Educational Sciences, University of Oslo.

Afdal, H. W. (2012b). Knowledge in teacher education curricula: Examining differences between a research-based program and a general professional program. Nordic Studies in Education, 32, 245-261. 
Afdal, H., \& Nerland, M. (2014). Does teacher education matter? An analysis of relations to knowledge among Norwegian and Finnish novice teachers. Scandinavian Journal of Educational Research, 58(3), 281-299.

Aspfors, J., \& Eklund, G. (2017). Explicit and implicit perspectives on research-based teacher education - newly qualified teachers' experiences in Finland. Journal of Education for Teaching - International Research and Pedagogy, 43(5), 400-413.

Aspfors, A., Eklund, G., Hansén S-E., \& Wikman, T. (2018). Equity, trust and autonomy Perspectives on teacher education in Finland. In K. G. Karras \& C. C. Wolhuter (Eds.), International handbook of teacher education (2th ed., vol. 1, pp. 511-525). Nicosia: HM Studies.

Aspfors, J., Hansén, S-E., \& Ray, J. (2013). Stability, structure and development. Features constituting Finnish teacher education. Scuola Democratica - Learning for Democracy, 3, 112. doi:10.12828/75800.

BERA-RSA (2014). Research and the teaching profession. Building the capacity for a selfimproving education system. Final report of the BERA-RSA inquiry into the role of research in teacher education. Retrieved from https://www.bera.ac.uk/wpcontent/uploads/2013/12/BERA-RSA-Research-Teaching-Profession-FULL-REPORT-forweb.pdf

Bezzina, C. (2007). Beginning teachers' perceptions about their induction in Malta. In M. Z. Zuljan \& J. Vogrinc (Eds.), Professional inductions of teachers in Europe and elsewhere (pp. 260-279). Ljubljana: University of Ljubljana, Faculty of Education.

Blömeke, S., \& Paine, L. (2008). Getting the fish out of the water: Considering benefits and problems of doing research on teacher education at an international level. Teaching and Teacher Education, 24, 2027-2037.

Braun, V., \& Clarke, V. (2006). Using thematic analysis in psychology. Qualitative Research in Psychology, 3(2), 77-101. doi:https://doi.org/10.1191/1478088706qp063o

Brouwer, N., \& Korthagen, F. (2005). Can teacher education make a difference? American Educational Research Journal, 42(1), 153-224.

Burn, K., \& Mutton, T. (2015). A review of 'research-informed clinical practice' in initial teacher education. Oxford Review of Education, 41(2), 217-233.

Cochran-Smith, M., \& Fries, K. (2008). Research on teacher education: Changing times, changing paradigms. In M. Cochran-Smith, S. Feiman-Nemser, J. McIntyre, \& K. Demers (Eds.), Handbook of research on teacher education: enduring questions in changing contexts. (3rd ed., pp. 1050-1093). New York, NY: Routledge.

Darling-Hammond, L. (2006). Constructing 21st-century teacher education. Journal of Teacher Education, 57(3), 300-314. 
Darling-Hammond, L. (2017). Teacher education around the world: What can we learn from international practice? European Journal of Teacher Education, 40(3), 291-309.

Day, C. (2007). Teachers Matter: Connecting Work, Lives and Effectiveness. McGraw-Hill Education (UK).

Finnish National Board on Research Integrity (TENK). (2016). Retrieved from http://www.tenk.fi/en/frontpage

Fletcher, E., Chang, J., \& Kong, Y. (2008). Organizational socialization applied to teacher induction: An emerging conceptual framework. Proceedings of the Academy of Human Resource Development International Research Conference in the Americas. Panama City, FL.

Griffiths, R. (2004). Knowledge production and the research-teaching nexus: The case of the built environment disciplines. Studies in Higher Education, 29(6), 709-726.

doi:10.1080/0307507042000287212

Hansén, S.-E., \& Eklund, G. (2014). Finnish teacher education - Challenges and possibilities. Journal of International Forum of Researchers in Education, 1(2), 1-12.

Hansén, S.-E., Eklund, G., \& Sjöberg, J. (2015). General didactics in Finnish teacher education - The case of class teacher education at Åbo Akademi University. Nordisk Tidskrift För Allmän Didaktik, 1(1), 7-20.

Hansén, S-E., Forsman, L., Aspfors, J., \& Bendtsen, M. (2012). Visions for teacher education - Experiences from Finland. Acta Didactica Norway, 6(1), 1-17.

Hatch, A. J. (2002). Doing qualitative research in education settings. Albany, NY: State University of New York Press.

Heikkinen, H., Jokinen, H., \& Tynjälä, P. (Eds.), (2012). Peer-group mentoring for teacher development. London: Routledge.

Heikkkinen, H., Wilkinson, J., Aspfors, J., \& Bristol, L. (2018). Understanding mentoring of new teachers: Communicative and strategic practices in Australia and Finland. Teaching and Teacher Education, 71, 1-11.

Hökkä, P., \& Eteläpelto, A. (2014). Seeking new perspectives on the development of teacher education. A study of the Finnish context. Journal of Teacher Education, 65(1), 39-52.

Jakku-Sihvonen, R., \& Niemi, H. (Eds.), (2006). Research-based teacher education in Finland - Reflections by Finnish teacher educators. Turku: Finnish Educational Research Association - Research in educational sciences 25.

Jakku-Sihvonen, R., Tissar, V., Ots, A., \& Uusiautti, S. (2012). Teacher education curriculum after the Bologna process - A comparative analysis of written curricula in Finland and Estonia. Scandinavian Journal of Educational Research, 56(3), 261-275. 
Jakhelln, R., Bjørndal, K. E., \& Stølen, G. (2016). Masteroppgaven - Relevant for grunnskolelæreren? [The master's theses - of relevance for the primary school teachere?] Acta Didactica Norge, 10(2), 193-211.

Kansanen, P. (2014). Teaching as a master's level profession in Finland: Theoretical reflections and practical solutions. In O. McNamara, J. Murray, \& M. Jones (Eds.), Workplace learning in teacher education. Professional learning and development in schools and higher education (pp. 279-292). Dordrecht: Springer.

Karlsen, G. (2014). Internasjonale aktører som premissgivere for norsk utdanningspolitikk med særlig vekt på OECD. In K. A., Røvik, T. V. Eilertsen, \& E. M. Furu (Eds.), Reformideer $i$ norsk skole. Spredning, oversettelse og implementering (pp. 121-146). Oslo: Cappelen Damm Akademisk.

Kemmis, S., \& Grootenboer, P. (2008). Situating praxis in practice: Practice architectures and the cultural, social and material conditions for practice. In S. Kemmis \& T. J. Smith (Eds.), Enabling praxis: Challenges for education (pp. 37-64). Rotterdam: Sense Publishers.

Kemmis, S., Heikkinen, H. L., Fransson, G., Aspfors, J., \& Edwards-Groves, C. (2014). Mentoring of new teachers as a contested practice: Supervision, support and collaborative selfdevelopment. Teaching and Teacher Education, 43, 154-164.

Kemmis, S., Wilkinson, J., Edwards-Groves, C., Hardy, L., I Grootenboer, P., \& Bristol, L. (2014). Praxis, practice and practice architectures. In S. Kemmis, J. Wilkinson, C. EdwardsGroves, I. Hardy, P. Grootenboer, \& L. Bristol (Eds.), Changing practices, changing education (pp. 25-41). New York, NY: Springer.

Koskenniemi, M., \& Hälinen, K. (1970). Didaktiikka; Lähinnä peruskouluja varten [Didactics; Primarily for the elementary school]. Helsinki: Otava.

Krokfors, L., Kynäslahti, H., Stenberg, K. Toom, A., Maaranen, K. Jyrhämä, R., Byman, R., \& Kansanen. P. (2011). Investigating Finnish teacher educators' views on research-based teacher education. Teaching Education, 22(1), 1-13.

Kynäslahti, H., Kansanen, P., Jyrhämä, R., Krokfors, L., Maaranen, K., \& Toom, A. (2006). The multimode programme as a variation of research-based teacher education. Teaching and Teacher Education, 22, 246-256.

Lahdes, E. (1969). Persukoulun opetusoppi [The didactics for elementary school]. Helsinki: Otava.

Lillejord, S., \& Børte, K. (2014). Partnerskap i 1arerutdanning - en forskningskartlegging KSU3-2014. [Partnership in teacher education - A review of the research]. Oslo:

Kunnskapssenter for utdanning. 
Lillejord, S., \& Børte, K. (2017). Larerutdanning som profesjonsutdanning - Forutsetninger og prinsipper fra forskning. Et kunnskapsgrunnlag [Teacher education as professional education - Conditions and principles from research. A knowledge base]. Oslo: Kunnskapssenter for utdanning.

Malinen, O-P., Väisänen, P., \& Savolainen, H. (2012). Teacher education in Finland: A review of a national effort for preparing teachers for the future. The Curriculum Journal, 23(4), 567 584.

Mausethagen, S. (2015). Lareren i endring? Om nye forventninger til larerprofesjonen og laererarbeidet. Oslo: Universitetsforlaget.

Muller, J. (2009). Forms of knowledge and curriculum coherence. Journal of Education and Work, 22(3), 205-226.

Munthe, E., \& Rogne, M. (2015). Research-based teacher education. Teaching and Teacher Education, 46, 17-24.

Møller, J. (2017). Leading education beyond what works. European Educational Research Journal, 16(4), 375-385.

Niemi, H., \& Jakku-Sihvonen, R. (2011). Teacher education in Finland. In M. V. Zuljan \& J. Vogrinc (Eds.), European dimensions of teacher education - Similarities and differences (pp. 33-52). Ljubljana: University of Ljubljana, Faculty of Education and the National School of Leadership in Education.

NOKUT. (2006). Evaluering av allmennlaererutdanningen $i$ Norge [Evaluation of the Norwegian teacher education for primary and lower secondary school]. Oslo: NOKUT.

The Norwegian Ministry of Education and Research. (2016a). Forskrift om rammeplan for grunnskolelaererutdanningene for 1.-7. trinn. [Regulations relating to the framework plan for primary and lower secondary teacher education for years 1-7]. Oslo: Regjeringen, Kunnskapsdepartementet.

The Norwegian Ministry of Education and Research. (2016b). Forskrift om rammeplan for grunnskolelaererutdanningene for 5.-10. trinn. [Regulations relating to the framework plan for primary and lower secondary teacher education for years 5-10]. Oslo: Regjeringen, Kunnskapsdepartementet.

The Norwegian National Research Ethics Committees. (2016). Guidelines for research ethics in the social sciences, humanities, law and theology. Retrieved from https://www.etikkom.no/en/

OECD. (2005). Teachers matter. Attracting, developing and retaining effective teachers.

Paris: OECD. Retrieved from

http://www.oecd.org/edu/school/attractingdevelopingandretainingeffectiveteachers-

finalreportteachersmatter.htm 
OECD. (2013). Education policy outlook Finland. Paris: OECD Publishing. Retrieved from http://www.oecd.org/education/EDUCATION\%20POLICY\%20OUTLOOK\%20FINLAND_ EN.pdf

Rindal, U., Lund, A., \& Jakhelln, R. (Eds.). (2015). Veier til fremragende laererutdanning. [Roads to excellent teacher education]. Oslo: Universitetsforlaget.

Rinne, R. (1984). Suomen oppivelvollisuuskoulun opetussuunnitelman muutokset vuosina 1916-1970: Opetussuunnitelman intentioiden ja lähtökohtien teoreettis-historiallinen tarkastelu. [The changes of the curriculum of Finnish compulsory education in 1916-1970: A theoretic-historical study into the intentions and basis of the curriculum]. Turun yliopisto: Akateeminen kirjakauppa.

Sahlberg, P. (2011). Finnish lessons. What can the world learn from educational change in Finland? New York, NY: Teachers Collegen Press, Columbia University.

Sandén, T., \& Wikman, T. (2010). En analys av metod och innehåll i klasslärares magisteravhandlingar [An analyse of method and containment in teachers' master's thesis]. In G. Eklund \& J. Sjöberg (Eds.), Att växa till lärare [Growing to teacher] (pp. 29-45). Vasa: Pedagogiska fakulteten, Åbo Akademi.

Sjølie, E. (2014). Pedagogy is just common sense. A case study of student teachers' academic learning practices (Unpublished doctoral dissertation). Norwegian University for Science and Technology.

Stake, R. E., \& Trumbull, D. (1982). Naturalistic generalizations. Review Journal of Philosophy and Social Science, 7(1), 1-12.

Stenhouse, L. (1975). An introduction to curriculum research and development. London: Heinemann.

Stølen, G. (2016). Hva ser jeg? Studentens forskerblikk i eget praksisfelt. [What do I see? The student's eye on her own practice]. In T. Leming, T. Tiller, \& E. Alerby (eds.), Forskerstudenten: Laererstudenter i nye roller. [The student researcher: Student teachers in new roles]. Oslo: Cappelen Damm Akademisk.

Thagaard, T. (2006). Systematikk og innlevelse: en innføring i kvalitativ metode [Systematics and involvement: An introduction into qualitative methods] (2nd ed.). Oslo: Fagbokforlaget.

Tirri, K. (2014). The last 40 years in teacher education. Journal of Education for Teaching, 40 (5), 600-609.

Toom, A., \& Husu, J. (2012). Finnish teachers as 'makers of the many'. Balancing between broad pedagogical freedom and responsibility. In H. Niemi, A. Toom, \& A. Kallioniemi (Eds.), The miracle of education: The principles and practice of teaching and learning in Finnish schools (pp. 39-54). Rotterdam: Sense Publishers. 
Toom, A., Kynäslahti, H., Krokfors, L., Jyrhämä, R., Byman, R., Stenberg, K., ... Kansanen, P. (2010). Experiences of a research-based approach to teacher education: Suggestions for future policies. European Journal of Teacher Education, 45(2), 331-344.

Trippestad, T. A., Swennen, A., \& Werler, T. (2017). The struggle for teacher education. In T. A., Trippestad, A. Swennen, \& T. Werler (Eds.), The struggle for teacher education: International perpsctives on governance and reforms (pp. 17-37). London: Bloomsbury Academic.

Tryggvason, M-T. (2009). Why is Finnish teacher education successful? Some goals Finnish teacher educators have for their teaching. European Journal of Teacher Education, 2(4), 369382.

Zeichner, K. (2014). The struggle for the soul of teaching and teacher education in the USA. Journal of Education for Teaching, 40(5), 551-568.

Özçınar, H. (2015). Mapping teacher education domain: A document co-citation analysis from 1992 to 2012. Teaching and Teacher Education, 47, 42-61. 